\title{
IDENTIFIKASI DAN PREVALENSI EKTOPARASIT PADA IKAN KERAPU TIKUS (Cromileptes altivelis) DI KARAMBA JARING APUNG UNIT PENGELOLA BUDIDAYA LAUT SITUBONDO
}

\section{IDENTIFICATION AND PREVALENCE OF ECTOPARASITES IN GROUPER (Cromileptes altivelis) AT FLOATING NET CAGE OF MARINECULTURE MANAGEMENT UNIT SITUBONDO}

\author{
Ferlyn Hendra Wiyatno, Sri Subekti dan Rahayu Kusdarwati \\ Fakultas Perikanan dan Kelautan Universitas Airlangga \\ Kampus C Mulyorejo - Surabaya, 60115 Telp. 031-5911451
}

\begin{abstract}
Grouper is a fish that lives in coral reefs, which is the internationally known as groupers or coral reef fishes. These fish have high economic value and potential to be developed in Indonesia. Grouper traded alive, the price is relatively high. The price of grouper at the level fishermen to reach US\$ 20 (Rp 200,000 , -) for each kilogram.These fish are exported mainly to Hong Kong with high price. Development of grouper aquaculture in floating net a viable alternative to overcome the increasing production of marine fisheries. The problem that often inhibiting fish culture is the diseases emergence, among others, caused by the parasites. The emergence of the disease is the result of interaction between environmental conditions that dont support the cultivation of their life inside, fish (host) that are sensitive and the presence of parasites. Uncontrolled environmental conditions there for the fish become stressed with poor immune systems, and facilitate pathogenic substance attacked hosts.

This study aimed to the identify ectoparasites that attacked the grouper (Cromileptes altivelis) in floating net cages and to determine the prevalence rate of ectoparasites that attacked the grouper (Cromileptes altivelis) in floating net cages.

The method of this study was descriptive method. Samples were taken with body length between $15-20 \mathrm{~cm}$ and four months old from the floating net. The main parameters observed in this study was identification of ectoparasites that attacked the grouper (Cromileptes altivelis) in floating net cages and prevalence rates for each of ectoparasites. While the supporting parameters were that water quality value in floating net cages as follow temperature, $\mathrm{pH}$ and salinity were measured during sampling activities.

The results showed that of 60 samples were taken from four plots of floating net cages, 21 fish infected with ectoparasites positive. 17 positive fishes infected Pseudorhabdosynochus sp., one sample positive infected Benedenia sp. 3samples positive infected fish Neobenedenia sp. The ectoparasites prevalence of from cages 1, 2, 3 and 4 of $26.66 \%, 33.33 \%, 53.33 \%$ and $26.66 \%$

The suggestion of this study is cleanness improvement of floating net cage management to reduce ectoparasites infectation.
\end{abstract}

Keywords : Identification, ektoparasite, Cromileptes altivelis, Floating Net Cage

\section{Pendahuluan}

Pengembangan budidaya laut

dilaksanakan untuk meningkatkan produksi ikan dan menggantikan produksi ikan dari hasil tangkap yang dilakukan secara berlebihan dan berdampak pada penurunan dan ancaman kepunahan populasi serta degradasi habitat. Pengembangan budidaya laut dapat menjadi salah satu mata pencaharian baru bagi nelayan pesisir pantai yang sekaligus dapat digunakan untuk peningkatan produksi pangan (protein ikan laut) bagi masyarakat. Salah satu jenis ikan laut yang memiliki nilai ekonomis penting adalah ikan kerapu tikus (Cromileptes altivelis) (Suburhan dkk, 2005).
Kerapu tikus merupakan ikan yang hidup di terumbu karang, yang dalam dunia internasional dikenal dengan nama groupers atau coral reef fishes. Ikan ini memiliki nilai ekonomis tinggi dan sangat potensial untuk dikembangkan di Indonesia. Ikan kerapu tikus diperdagangkan dalam keadaan hidup, dengan harga jual yang relatif tinggi. Harga ikan kerapu tikus di tingkat nelayan dapat mencapai US\$ $20 \quad(\mathrm{Rp}$ 200.000,-) untuk setiap kilogramnya. Ikan tersebut di ekspor terutama ke Hongkong dengan harga jual yang berlipat. Pada tahun 2000, Hongkong mengimpor 9.827 ton ikan kerapu hidup, dengan pemasok utama China, Thailand, Philipina, Indonesia, 
Australia dan Malaysia (Muchtadi, 2007).

Bedasarkan data Direktorat Jendral

Perikanan Budidaya (2011), produksi ikan kerapu di Indonesia pada tahun 2004 sampai dengan 2010 cukup baik walaupun sempat mengalami penerunan produksi pada tahun 2008, tetapi pada tahun selanjutnya terus mengalami kenaikan bahkan pada tahun 2010 yang lalu produksi naik secara signifikan. Kenaikan rata-rata ikan kerapu empat tahun terakhir ini sebesar 18,72 persen dan kenaikan tertinggi pada empat tahun terakhir ini terletak pada tahun 2010 dengan kenaikan produksi sebesar 18,28 persen. Kenaikan produksi naik dari tahun 2009 sebesar 8,791 ton menjadi 10,398 ton pada tahun 2010. Produksi kerapu di Indonesia berasal dari dua sumber yaitu penangkapan dilaut dan hasil pembudidayaan. Untuk memenuhi permintaan akan kesediaan ikan kerapu yang terus meningkat, usaha budidaya merupakan salah satu peluang usaha yang masih sangat terbuka luas. Untuk menunjang produksi kerapu di Indonesia maka tersedianya benih sangat penting, namun banyak kendala yang harus dihadapi dalam pemeliharaan benih kerapu tersebut. Salah satu kendala yang paling besar adalah tingginya mortalitas benih ikan kerapu. Salah satu penyebab mortalitas yang tinggi pada benih kerapu adalah dari faktor penyakit. Penyakit terjadi akibat adanya interaksi antara inang (ikan), bahan patogen dan lingkungan. Kondisi lingkungan yang buruk dapat menyebabkan stres dan penurunan daya tahan tubuh ikan terhadap penyakit.

Pengembangan budidaya ikan kerapu dengan karamba jaring apung menjadi alternatif untuk mengatasi kendala peningkatan produksi perikanan laut. Keuntungan sistem karamba jaring apung adalah padat penebaran tinggi, tidak memerlukan pengolahan tanah, mudah pengendalian gangguan pemangsa dan mudah dalam pemanenan. Hal paling penting dengan pengembangan usaha ini adalah, bahwa harga jual produksi dari tahun ke tahun semakin baik dan sangat prospektif. Selain itu dengan teknologi budidaya karamba ini, produksi ikan dapat dipasarkan dalam keadaan hidup, dimana untuk pasaran ekspor ikan hidup nilainya lebih mahal hingga mencapai 10 kali lipat dari pada ekspor ikan segar (Mandhani dkk, 2010).

Budidaya ikan kerapu di Indonesia sudah mulai berkembang terutama di karamba jaring apung di laut. Salah satu masalah yang sering menghambat budidaya ikan ini adalah munculnya penyakit, antara lain disebabkan oleh parasit ikan. (Bunga dkk, 2009).
Penyakit merupakan salah satu faktor kendala dalam kegiatan budidaya yang dikarenakan oleh ketidakseimbangan interaksi antara faktor lingkungan, inang, dan agen penyakit. Faktor lingkungan dalam hal ini dapat berperan sebagai pemicu terjadinya stres bagi inang akibat perubahan fisik, kimia, dan biologis lingkungan tersebut sehingga daya tahan tubuh menurun dan menjadi rentan terhadap serangan penyakit (Irianto, 2003).

Parasit merupakan organisme yang hidup pada atau di dalam organisme lain dan mengambil makanan dari organisme yang ditumpanginya untuk berkembang biak (Subekti dan Mahasri, 2010). Parasit dapat merugikan inangnya karena mengambil makanan pada tubuh inangnya selain itu, parasit adalah suatu organisme yang mengambil bahan untuk kebutuhan metabolismenya (makanan) dari tubuh inangnya dan merugikan bagi inang tersebut. Sehingga parasit tidak dapat hidup lama di luar tubuh inangnya (Alifuddin, 2004). Menurut Supriyadi (2004) berdasarkan sifat hidupnya parasit dapat dibedakan menjadi dua golongan, yaitu obligat dan fakultatif. Obligat yaitu parasit yang hanya bisa hidup jika berada pada inang. Fakultatif yaitu parasit yang mampu hidup di lingkungan air jika tidak ada inang di sekitarnya.

Berdasarkan predileksi, parasit dapat dibedakan menjadi ektoparasit, endoparasit dan mesoparasit. Ektoparasit adalah parasit yang hidup pada bagian luar tubuh inang, endoparasit adalah parasit yang hidup di dalam tubuh inang. Sedangkan mesoparasit adalah parasit yang sebagian tubuh endoparasit dan sebagian yang lain ektoparasit (Subekti dan Mahasri, 2010).

Parasit yang biasanya menyerang ikan kerapu adalah Benedenia epinepheli, Caligus epinepheli, Ergasilus, Diplectanum grouperi, Dactylogyrus, Neobenedenia girellae, Haliotrema epinepheli, Pseudorhabdosynochus seabasi, dan Trichodina.

Kerugian parasit yang menyerang ikan pada permukaan tubuh atau kulit antara lain ikan akan terlihat pucat dan timbul lendir secara berlebihan. Organisme yang menyerang bagian permukaan tubuh dapat berasal dari golongan bakteri, virus, jamur atau lainnya. Ikan yang terinfeksi ektoparasit pada kulitnya, akan menggosok-gosokkan badan pada benda di sekelilingnya sehingga sering kali menimbulkan luka baru yang dapat menyebabkan terjadinya infeksi sekunder, sedangkan penyakit pada insang agak sulit untuk dideteksi secara dini karena menyerang bagian dalam ikan. Salah satu cara yang dianggap cukup efektif untuk mengetahui adanya infestasi ektoparasit insang 
adalah mengamati tingkah laku ikan. Ciri utama ikan yang terserang organ insang adalah menjadi sulit untuk bernafas, selain itu tutup insang akan mengembang sehingga sulit untuk ditutup dengan sempurna. Jika serangannya sudah meluas, lembaran insang menjadi semakin pucat. Sering pula dijumpai adanya bintik-bintik merah pada insang yang menandakan telah terjadi pendarahan (peradangan). Jika terlihat bintik putih pada insang, kemungkinan besar disebabkan oleh serangan parasit kecil yang menempel (Handajani, 2010).

\section{Metodologi}

Peralatan penelitian yang akan digunakan dalam pemeriksaan parasit adalah gunting, pinset, pisau bedah dan nampan. Alat yang digunakan untuk identifikasi parasit adalah obyek gelas, cover gelas, dan mikroskop. Bahan yang diperlukan untuk proses identifikasi ektoparasit adalah ikan kerapu tikus sebanyak 60 ekor dengan ukuran panjang 15-20 cm yang diambil dari 4 rakit karamba jaring apung milik Unit Pengelola Budidaya Laut, Situbondo. Bahan yang digunakan untuk pemeriksaan parasit adalah ikan sampel, tisu dan aquades sedangkan bahan yang digunakan untuk pewarnaan parasit yang ditemukan adalah larutan $\mathrm{NaCl}$ jenuh, alkohol gliserin 5\%, PZ, alkohol 70\%, $\mathrm{HCl}, \mathrm{NaHCO}_{3}$, alkohol 85\%, alkohol 95\%, larutan Hung's I dan larutan Hung's II (Pewarnaan Semichen-Acetic Carmine).

Metode penelitian yang digunakan dalam penelitian ini adalah metode survei. Metode survei merupakan upaya pengumpulan informasi dari sebagian populasi yang dianggap dapat mewakili populasi tertentu (Mantra, 2001).

Persiapan yang dilakukan adalah melakukan sterilisasi gunting, pinset, pisau bedah dan nampan sebelum digunakan, yaitu mencuci hingga bersih alat tersebut menggunakan sabun kemudian dikeringkan. Selanjutnya mempersiapkan ikan sampel yang akan diamati dengan mengambil secara acak.

Pengambilan sampel pada tiap karamba jaring apung sebanyak 15 ekor yaitu sebesar 7\% dari jumlah populasi. Pengambilan sampel dilakukan satu kali dengan jumlah sampel sebanyak 60 ekor dengan kisaran panjang tubuh ikan antara $15-20 \mathrm{~cm}$ dan umur empat bulan dari empat karamba jaring apung. Lokasi pengambilan sampel ikan ditentukan dengan cara sengaja atau dengan metode purposive sampling (Bunga, 2008). Metode pengambilan sampel dilakukan secara acak (random sampling) terhadap ikan dari karamba jaring apung di Unit Pengelola Budidaya Laut, Situbondo. Sampel dimasukkan ke dalam kantong plastik dan diberi oksigen kemudian dibawa ke Laboratorium Kesehatan Lingkungan Balai Budidaya Air Payau Situbondo, kemudian ditampung dalam wadah akuarium dan diaerasi. Pemeriksaan ektoparasit meliputi bagian permukaan tubuh, sirip dan insang. Pemeriksaan dilakukan dengan pengerokan (scrapping) pada permukaan tubuh, sirip dan ekor. kemudian diperiksa dibawah mikroskop dengan pembesaran 100x dan 400x. Setelah mendapatkan ektoparait kemudian dilakukan pewarnaan ektoparasit menggunakan metode Semichen-Acetic Carmine .

Prevalensi adalah besarnya persentase ikan yang terinfestasi dari ikan contoh yang diperiksa (Karantina Ikan kelas II Tanjung Emas, 2009).

Prevalensi dihitung dengan menggunakan rumus sebagai berikut :

Prevalensi $=$ Jumlah ikan yang terserang

Jumlah sampel ikan yang diperiksa

Pada penelitian ini parameter utama yang diamati meliputi jenis ektoparasit yang menyerang ikan kerapu dan prevalensi. Parameter penunjang, yaitu kualitas air meliputi suhu, salinitas dan $\mathrm{pH}$. Pengukuran suhu dilakukan dengan termometer, salinitas di ukur menggunakan Refraktometer dan $\mathrm{pH}$ dengan $\mathrm{pH}$ paper. Pengukuran parameter kualitas air kolam dilakukan satu kali yaitu pada waktu pengambilan sampel

Penelitian ini bersifat deskriptif, data hasil penelitian akan disajikan dalam bentuk gambar dan tabel, data yang terkumpul dianalisis secara deskrptif (Steel and Torrie, 1993).

\section{Hasil dan Pembahasan}

Hasil identifikasi ektoparasit pada permukaan tubuh (kulit) ikan ditemukan dua spesies cacing ektoparasit yaitu : Benedenia dan Neobenedenia sedangkan pada insang ditemukan satu jenis cacing ektoparasit yaitu: Pseudorhabdosynochus. Dari ketiga cacing tersebut dapat dilihat pada gambar di bawah ini. 


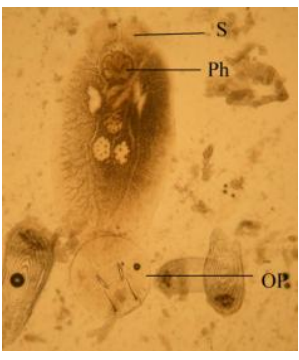

Benedenia

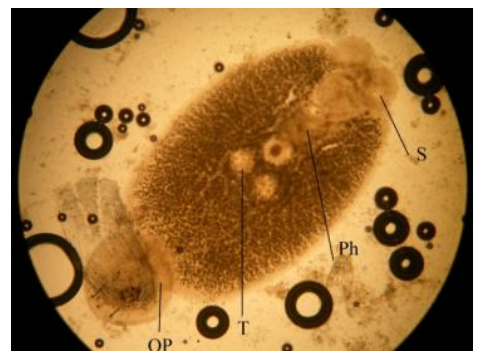

Neobenedenia

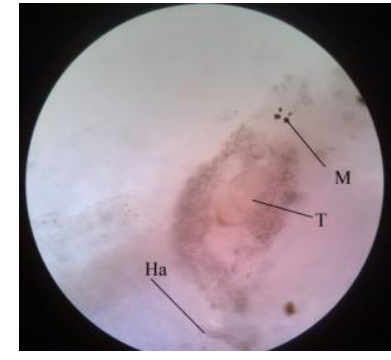

Pseudorhabdosynochus
Hasil prevalensi terhadap 15 sampel yang di ambil dari masing-masing karamba jaring apung di Unit Pengelola Budidaya Laut Situbondo diperoleh data dengan rincian dari karamba jaring apung pertama didapat empat sampel positif terserang cacing ektoparasit Pseudorhabdosynochus dan 11 ikan yang negatif dengan prevalensi sebesar 26,66\%, karamba jaring apung kedua diperoleh lima sampel positif terserang Pseudorhabdosynochus, Benedenia, dan Neobenedenia dan 10 ikan yang negatif dengan prevalensi sebesar 33,33\%, karamba jaring apung ketiga diperoleh delapan sampel positif terserang Pseudorhabdosynochus dan Neobenedenia dan tujuh ikan negatif dengan prevalensi sebesar 53,33\%, dan karamba jaring apung keempat diperoleh empat sampel terserang ektoparasit jenis Pseudorhabdosynochus dan 11 ikan yang negatif dengan prevalensi sebesar 26,66\%. Prevalensi tertinggi berada pada karamba ketiga dengan prevalensi sebesar $53,33 \%$ dan prevalensi terendah pada karamba kesatu dan keempat dengan prevalensi sebesar $26,66 \%$. Nilai prevalensi keseluruhan untuk budidaya ikan kerapu tikus pada karamba jaring apung di Unit Pengelola Budidaya Laut Situbondo sebesar $35 \%$.

Bedasarkan hasil pemeriksaan yang dilakukan pada permukaan tubuh dan insang ikan kerapu tikus (Cromileptes altivelis), diperoleh 21 ikan yang positif terinfeksi ektoparasit. Hasil penelitian ini menunjukkan bahwa nilai prevalensi pada beberapa karamba di Unit Pengelola Budidaya Laut Situbondo memiliki nilai yang berbeda-beda. Prevalensi pada karamba pertama sebesar 26,66\%, karamba kedua sebesar 33,33\%, karamba ketiga sebesar 53,33\% dan karamba keempat sebesar $26,66 \%$ Hal ini kemungkinan disebabkan menejemen pemeliharaan ikan yang kurang baik yaitu kurang diperhatikannya masalah kebersihan jaring dalam proses budidaya dan masalah tidak terkontrolnya kualitas air karena hanya bergantung pada musim. Hal ini disebabkan pada saat penelitian dilakukan, sedang terjadi perubahan musim yaitu terjadinya angin barat yang menyebabkan gelombang serta arus semakin tinggi dan dapat menyebabkan terganggunya proses budidaya. Kordi (2005) mengemukakan bahwa arus yang berlebihan harus dicegah, sebab disamping dapat merusak posisi karamba juga dapat menyebabkan stres pada ikan.

Dilihat dari prevalensinya karamba ketiga menunjukkan tingkat prevalensi cacing ektoparasit paling tinggi, yaitu sebesar 53,33\% hal ini disebabkan karena karamba ketiga memiliki kondisi yang kotor sehingga kemungkinan dapat digunakan sebagai tempat melekatnya telur cacing untuk penyebaran cacing ektoparasit pada ikan. Sedangkan prevalensi terendah berada pada karamba pertama dan ke empat, tingkat prevalensi cacing ektoparasit sebesar 26,66\%. Hal ini disebabkan karena pada karamba pertama dan keempat memiliki kondisi jaring yang lebih bersih dibanding jaring yang ada pada karamba kedua dan ketiga, selain itu nilai kualitas air juga masih dalam keadaan normal sehingga memiliki nilai prevalensi yang rendah. Menurut Diba (2009) menyatakan bahwa rendahnya tingkat prevalensi disebabkan oleh keadaan endemik suatu parasit, kemampuan adaptasi parasit di tubuh inang dan kecocokan inang untuk kelangsungan hidup parasit dan kualitas lingkungan. Selain itu padat tebar yang rendah juga mempengaruhi keberadaan cacing ektoparasit karena ruang gerak dan makanan bagi ikan masih dalam kondisi yang normal sehingga tidak terjadi kompetisi dalam hal mencari makanan dan ruang gerak.

Dilihat dari prevalensi secara keseluruhan pada budidaya ikan kerapu tikus di karamba jaring apung Unit Pengelola Budidaya Laut Situbondo yaitu sebesar 35\%, dapat dikatakan masih rendah. Hal ini dikarenakan 
masih terkontrolnya kualitas air sehingga tidak juga ditemukan parasit lain pada phylum Protozoa dan Arthropoda.

Bedasarkan hasil penelitian ini, telah diidentifikasi tiga jenis cacing ektoparasit yang menginfestasi ikan kerapu tikus (Cromileptes altivelis) pada karamba jaring apung di Unit Pengelolah Budidaya Laut Situbondo yaitu Benedenia, Neobenedenia, dan Pseudorhabdosynochus.

Benedenia menunjukkan tingkat prevalensi sebesar $1,66 \%$. Subekti dan Mahasri (2010) menyatakan bahwa Benedenia memiliki habitat pada kulit, mata, rongga hidung dan insang dan apabila parasit ini menginfeksi dalam jumlah banyak, sehingga dapat menyebabkan terjadinya kematian pada ikan. Parasit ini termasuk dalam ordo Dactylogyridea dan famili Capsylidae yang mempunyai bentuk tubuh pipih, dan memiliki satu pasang sucker pada bagian anterior tubuh, serta opisthaptor yang membulat pada bagian posterior tubuh, selain itu Benedenia memiliki ciri yang khas yaitu memiliki bentuk pharinx yang bergelombang (gilig). Hal ini sesuai dengan pernyataan Jithendran et al, (2005) yang menyatakan bahwa parasit ini memiliki bentuk pipih dorso ventral dengan tubuh memanjang, dengan ukuran tubuh 2,05-3,29 x 0,66-1,33 mm dan memiliki dua pasang bintik mata pada bagian anterior dan posterior. Bintik mata bagian anterior memiliki ukuran lebih kecil dari pada posterior. Pada Ujung posterior tubuh terdapat piringan (disk) seperti opisthaptor dilengkapi dengan kait. Ujung anterior memiliki sepasang alat penghisap (ophistaptor) dengan diameter rata-rata $0,19 \mathrm{~mm}$.

Cacing Neobenedenia ini termasuk Ordo Dactylogyridea, Famili Capsilidae. Monogenean Capsalid dikenal sebagai cacing kulit dan merupakan parasit eksternal yang paling umum pada budidaya ikan laut selain itu cacing ini berbentuk pipih dorso ventral dan memiliki pharinx berbentuk bulat dan memiliki vitelene yang tersebar pada tubuhnya sampai pada ujung anterior opistapthor, selain itu cacing ini memiliki sepasang sucker pada ujung anterior tubuh dan opistapthor pada posterior tubuh. Hal ini sesuai dengan pernyataan Johnny dkk, 2002, menyatakan bahwa Capsalid meliputi beberapa spesies dan mempunyai kesamaan morfologi yaitu berbentuk oval (lonjong) dengan sepasang sucker bulat (anterior sucker) pada tepi bagian depan dan sebuah haptor besar (opistapthor) pada tepi bagian posterior.

Pseudorhabdosynochus termasuk dalam ordo Dactylogyridea dan famili
Diplectanidae. Parasit ini tubuhnya berbentuk ovoid dan pada bagian anterior memiliki dua pasang bintik mata serta memiliki haptor pada bagian posterior tubuh selain itu cacing ini memiliki kekhasan yaitu mempunyai bentuk organ kopulatori yang berbeda pada setiap spesies dan terletak pada anterior tubuh. Hal ini sesuai dengan pernyataan Wo, et al (2005) menyatakan bahwa Pseudorhabdosynochus memiliki bentuk tubuh silinder dengan panjang total 654 dan lebar $233 \mu \mathrm{m}$, pada bagian anterior dilengkapi dengan dua pasang bintik mata yang berbeda, pada bagian posterior memiliki haptor dengan panjang 48 mikron meter serta memiliki organ kopulatori berupa testis dan ovarium yang terdapat dalam tubuhnya.

\section{Kesimpulan}

Kesimpulan dari penelitian tentang identifikasi dan prevalensi ektoparasit pada ikan kerapu tikus (Cromileptes altivelis) pada karamba jaring apung di Unit Pengelola Budidaya Laut Situbondo adalah sebagai berikut : jenis ektoparasit yang ditemukan pada ikan kerapu tikus (Cromileptes altivelis) pada karamba jaring apung di Unit Pengelola Budidaya Laut Situbondo yaitu Benedenia, Neobenedenia, dan Pseudorhabdosynochus. Prevalensi cacing ektoparasit pada karamba jaring apung di Unit Pengelola Budidaya Laut Situbondo sebesar 35\%. Hal ini menunjukan bahwa tingkat prevalensi tergolong rendah.

Bedasarkan hasil penelitian ini disarankan untuk dilakukannya pengamatan prevalensi yang berkelanjutan untuk mengetahui penularan parasit pada setiap ikan. Salah satu usaha yang dilakukan yaitu dengan memutus daur hidup dari parasit dengan dilakukannya perbaikan manajemen terhadap kebersihan karamba agar dapat mengurangi angka infeksi ektoparasit yang ada pada karamba.

\section{Daftar Pustaka}

Alifuddin, M. 2004. Diagnostik dan Pewarnaan Sediaan Parasit. Dalam: Pelatihan Dasar Karantina Ikan Tingkat Ahli dan Terampil. Pusat Karantina Ikan. Agustus 2004. Bogor.15 hal.

Bunga, M. 2008. Prevalensi dan Intensitas Serangan Parasit Diplectanum sp. Pada Insang Ikan Kerapu Macan (Epinephelus fuscoguttatus, Forsskal) di Keramba Jaring Apung. Jurnal Ilmu Kelautan dan Perikanan 18 (3) : 204-210.

Bunga, M., Rantetondok, A., dan Ansyari, H. 2009. Tingkat Infeksi, Mikrohabitat dan Patologis Parasit Diplectanum sp Pada 
Insang Ikan Kerapu Macan (Epinephelus fuscoguttatus) Di Keramba Jaring Apung. Jurnal Sains dan Teknologi. 7374.

Diba, D.F. 2009. Prevalensi dan Intensitas Infestasi Endoparasit Berdasarkan Hasil Analisis Feses Kura-kura Air Tawar (Coura amboinensis) di Perairan Sulawesi Selatan. Tesis. Sekolah Pascasarjana. Institut Pertanian Bogor. Bogor. 47 hal.

Direktorat Jendral Perikanan Budidaya. 2011. Target Produksi Nasional Kerapu Tercapai 148,55 persen, Semua Provinsi Mencapai Target. Ditjen Perikanan Budidaya.

Handajani, H. 2010. Parasit dan Penyakit Ikan. Universitas Muhamadyah Malang. Jawa Timur.

Irianto, A. 2003. Probiotik Akuakultur. Gajah Mada University. Yogyakarta.

Jithendrand. K. P, K. K. Vijayan, S. V. Alavandi and M. Kailasam. 2005. Benedenia epinepheli (Yamaguti 1937), A Monogenean Parasite in Captive Broodstock of Grouper, Epinephelus tauvina (Forskal). Asian Fisheries Science. Central Institute of Brackishwater Aquaculture. India. 121$126 \mathrm{p}$.

Johnny. F, D. Roza dan Prisdiminggo. 2002. Kejadian Penyakit Infeksi Parasit Pada Ikan Kerapu Di Keramba Jaring Apung Teluk Ekas, Kabupaten Lombok Timur, Nusa Tenggara Barat.Balai Besar Riset Perikanan Budidaya Laut Gondol, Bali dan Balai Pengkajian Teknologi Pertanian Nusa Tenggara Barat.

Karantina Ikan Kelas II Tanjung Emas. 2009. Laporan Pemantauan Hama dan Penyakit Ikan Karantina (HPIK). Balai Karantina Ikan Kelas II Tanjung Emas Semarang. 43 hal.

Mandhani. J, I. Handito, R. Santoso, W. Pratiwi. 2010. Penyuluhan Budidaya Ikan Kerapu di Keramba Jaring Apung Terhadap Masyarakat Nelayan Ikan Tangkap. PKM-M. Universitas Airlangga. Surabaya.
Mantra, I.B. 2001. Langkah-langkah Penelitian Survai Usulan Penelitian dan Laporan Penelitian. Yogyakarta: Badan Penerbit Fakultas Geografi (BPFG) - UGM.

Muchtadi, T. R. 2007. Riset Unggulan Strategi Nasional Peningkatan Produk Pangan Hewani. Dupeti Bidang Pengembangan Sipteknas. Kementrian Negara Riset dan Teknologi RI.

Steel R. G. and Torrie J. H. 1993. Prinsip Prosedur Statistika. Terjemahan Oleh Bambang Sumantri. Gramedia Jakarta.

Subekti, S dan G, Mahasri. 2010. Parasit dan penyakit Ikan (Trematodiasis dan Cestodiasis). Fakultas Perikanan dan Kelautan Universitas Airlangga. Surabaya. 30-50 hal.

Suburhan, W. A. W. Hasan, M. A. L. Halipa, F. E. Noviyanti. 2005. Usaha Pengelondongan ikan Kerapu Bebek (Cromileptes altivelis) untuk mendukung Pengembangan Budidaya Laut di Sulawesi Tenggara. PKM-K. Jurusan Perikanan, Universitas Haluoleo. Kendari

Supriyadi, H, 2004. Pencegahan Penyakit Ikan Hias. Dalam: Pelatihan Dasar Karantina Ikan Tingkat Ahli dan Terampil. Pusat Karantina Ikan. Agustus 2004. Jakarta. 6 hal.

Wu, X. Y., A. X. Li., X. Q. Zhu and M. Q. Xie. 2005. Description

Pseudorhabdosynochus (Monogenea: Diplectanidae) from Lates calcarifer and revision of the phylogenetic position of Diplectanum grouperi(Monogenea: Diplectanidae) based on rDNA sequence data. Sun Yatsea University. China. 231-240 p 